\title{
Reduced Sensitivity in Monilinia fructicola to Propiconazole in Georgia and Implications for Disease Management
}

\author{
Guido Schnabel and P. Karen Bryson, Department of Entomology, Soils and Plant Sciences, and William C. \\ Bridges, Department of Experimental Statistics, Clemson University, Clemson SC 29634; and Phillip M. Brannen, \\ Department of Plant Pathology, University of Georgia, Athens 30602
}

\begin{abstract}
Schnabel, G., Bryson, P. K., Bridges, W. C., and Brannen, P. M. 2004. Reduced sensitivity in Monilinia fructicola to propiconazole in Georgia and implications for disease management. Plant Dis. 88:1000-1004.

Single-spore isolates of Monilinia fructicola were collected from commercial orchards in South Carolina and Georgia with prolonged past exposure to demethylation inhibitor (DMI) fungicides and from an orchard with no DMI history (baseline population). Sensitivity to propiconazole was determined using the concentration in agar media required to suppress radial growth of mycelium by $50 \%\left(\mathrm{EC}_{50}\right)$. Mean $\mathrm{EC}_{50}$ values from six South Carolina populations were not different from the baseline population $(P<0.05)$. Two of five populations from Georgia revealed significantly higher mean $\mathrm{EC}_{50}$ values compared with the baseline population $(P<0.05)$. Isolates with high (AP5 and AP6) and low (DL71 and DL72) $\mathrm{EC}_{50}$ values were selected to determine disease incidence on peach fruit after protective or curative applications of propiconazole at 0.15 or 0.3 liter/ha (half and full label rate, respectively). Disease incidence was significantly greater on peaches inoculated with AP5 and AP6 after curative treatment with propiconazole at 0.15 liter/ha $(P<0.05)$. Following protective or curative treatments at 0.3 liter/ha, disease incidence was significantly greater for AP6 but not for AP5. These results suggest that a shift toward reduced sensitivity has developed in some $M$. fructicola populations from Georgia, and that isolates with reduced sensitivity to propiconazole are more difficult to control in the field. Field testing of DMI fungicides, captan, $\mathrm{Q}_{\mathrm{O}} \mathrm{I}$ fungicides, and fenhexamid in experimental orchards indicated that the DMI fungicides are still among the most efficacious products for brown rot control, and that new products containing $\mathrm{Q}_{0} \mathrm{I}$ fungicides may be viable disease control alternatives or rotation partners.
\end{abstract}

Demethylation inhibitor (DMI) fungicides are very effective materials for blossom blight and brown rot control in stone fruits in the southeastern United States and many other production areas of the world. They specifically bind to the sterol $14 \alpha-$ demethylase and therefore inhibit sterol biosynthesis in the fungal cell walls. First introduced in the early 1980s, they gradually replaced the benzimidazoles after benzimidazole resistance was reported in Monilinia species $(8,23)$. Until recently, brown rot and blossom blight control were dependent on members of the DMI fungicides because other registered products were often less efficacious in comparative studies.

Reduced sensitivity in M. fructicola to DMI fungicides can develop after pro-

Corresponding author: G. Schnabel

E-mail: schnabe@clemson.edu

This research was supported by the South Carolina Peach Council.

Technical Contribution No. 4965 of the Clemson University Experiment Station.

Accepted for publication 27 April 2004.

Publication no. D-2004-0701-01R

(C) 2004 The American Phytopathological Society longed, repeated exposure in the field (22). The range of sensitivity of baseline populations can widen, and isolates with reduced sensitivity can develop after a total of only 12 applications in 3 years (22). The practical significance of field isolates with reduced sensitivity to DMI fungicides has not been established. However, it is surprising that effective field disease control has been maintained in most peach growing areas of the southeastern United States and elsewhere after more than 15 years of consecutive DMI fungicide use.

Some growers in Georgia have experienced significant outbreaks of brown rot in recent years, despite preharvest applications of DMI fungicides. The reason for these outbreaks is not known. The outbreaks usually coincided with very moist, rainy weather during the peach ripening periods, which may indicate either that materials were washed off by rain during or after application or that the materials were not effective enough to prevent brown rot epidemics, possibly due to favorable weather for infection and rapid disease development. On the other hand, wet weather during peach ripening does not necessarily cause a brown rot epidemic. For example, no serious epidemic was reported in South Carolina orchards during the wet 2001 and 2003 peach har- vest seasons. The availability of brown rot inoculum does play a role in whether an epidemic occurs, but it is also possible that the recent outbreaks are connected with reduced sensitivity in $M$. fructicola to DMI fungicides.

In recent years, new products with modes of action other than inhibition of sterol biosynthesis have been registered for brown rot control. The usefulness of these compounds for the southeastern United States is being explored in field tests $(15,16)$. Examples of new compounds are fenhexamid, azoxystrobin, pyraclostrobin, and boscalid. Fenhexamid is a hydroxyanilide that inhibits germ tube elongation and mycelial growth at low concentrations and spore germination at high rates. Azoxystrobin, pyraclostrobin, and boscalid are fungal respiration inhibitors that are primarily used protectively for disease control, but curative and eradicative action has been reported $(14,18)$. Boscalid differs from pyraclostrobin and azoxystrobin in both its mode and site of action. It inhibits the enzyme succinate ubiquinone reductase, also known as complex II, in the mitochondrial electron transport chain, whereas pyraclostrobin and azoxystrobin inhibit electron transport in the mitochondrial respiratory chain at the $b_{1}$ complex, also known as complex III (1). Boscalid and pyraclostrobin were only available as a mixture during this study.

The objectives of this study were to determine (i) if $M$. fructicola collected from commercial peach orchards in Georgia and South Carolina with prolonged exposure to DMI fungicides exhibited reduced sensitivity to propiconazole, (ii) if isolates with reduced sensitivity in vitro could be controlled effectively in peach assays with a DMI fungicide, and (iii) if fungicides newly registered for brown rot control could be useful in resistance management programs.

\section{MATERIALS AND METHODS}

Origin and collection of single-spore isolates of $M$. fructicola. Brown rot diseased peaches were collected in 2000 from an abandoned orchard (Baseline DL) in Anderson County, SC, and in 2001 to 2003 from various commercial orchards in South Carolina and Georgia. The Baseline DL orchard was at least $1 \mathrm{~km}$ away from the nearest commercial orchard and had never been sprayed with DMI fungicides. 
Commercial peach orchards in South Carolina (CC02, EZ, SY, CC03, MC, and BS) and Georgia (DF, LO, JO, AP, and DL03) had been treated regularly with DMI fungicides during bloom and preharvest for 3 to 10 years. In 2001, diseased fruit was collected from orchards in three counties in South Carolina; two were located in the Ridge (west central). In 2002, diseased fruit was collected primarily from grower orchards in Georgia because of extremely low brown rot incidence in South Carolina. In 2003, diseased fruit was collected from the Ridge and the Piedmont (extreme north) parts of South Carolina and from Georgia counties. Diseased fruit collected in 2001, 2002, and 2003 represented three, three, and five commercial growers, respectively. No more than one fruit was collected from a single tree.

M. fructicola conidia were scraped from each diseased fruit with a sterile toothpick and transferred to $1 \mathrm{ml}$ of water. The conidial suspension was vortexed, and $50 \mu \mathrm{l}$ was evenly distributed onto water agar amended with streptomycin sulfate at 100 $\mu \mathrm{g} / \mathrm{ml}$ in petri dishes $(15 \times 90 \mathrm{~mm})$. A hyphal tip from a germinating conidium was transferred aseptically to potato dextrose agar (PDA; Difco Laboratories, Sparks, MD). Only one single-spore culture per fruit was used for this study.

In vitro sensitivity of $M$. fructicola isolates to propiconazole. Sensitivity to propiconazole was determined using fungicide-amended agar medium as described previously (22) and expressed as the concentration in agar medium required to suppress radial growth of mycelium by $50 \%\left(\mathrm{EC}_{50}\right)$. Propiconazole (Orbit 3.6EC) was added at final concentrations of 0 , $0.001,0.005,0.01,0.05,0.1,0.5$, and 1.0 $\mu \mathrm{g} / \mathrm{ml}$. Sensitivity factors for a population were calculated by dividing the highest $\mathrm{EC}_{50}$ value by the lowest $\mathrm{EC}_{50}$ value of isolates within a population.

Effect of propiconazole treatments on development of $M$. fructicola isolates exhibiting differential sensitivity. $M$. fructicola isolates with low (DL71 and DL72) and high (AP5 and AP6) $\mathrm{EC}_{50}$ values were selected to determine their sensitivity to propiconazole (Orbit 3.6EC) in peach inoculation studies. Cresthaven peaches were grown at the Musser Fruit Research Station, Clemson University, and sprayed prior to harvest on 15 and 23 July with the fungicide fenbuconazole (Indar 75WSP) at label rate to prevent preharvest brown rot. Fruit was harvested at commercial shipping maturity and stored at $3{ }^{\circ} \mathrm{C}$ until experiments were conducted (but no longer than 4 weeks). For each experiment, peaches were placed in carbon-fiber trays $(4 \times 6$ pockets $) 24 \mathrm{~h}$ before inoculation, and the fruit surface was cleaned with wet wipes to remove any potential protective fungicide residues. To adjust the fruit temperature, peaches were kept at $22^{\circ} \mathrm{C}$ overnight prior to inoculation. Peach inocula- tion was performed as described previously by Hong et al (5). Briefly, each peach was injured once at the upper surface with a sterile needle $(1.5 \mathrm{~mm}$ diameter); immediately thereafter, a $20-\mu \mathrm{l}$ drop of a spore suspension $\left(4 \times 10^{5}\right.$ conidia per $\mathrm{ml}$ ) of M. fructicola isolates DL71, DL72, AP5, or AP6 was placed on top of the injured site. For each isolate, four peaches in each of four replicates were inoculated. Empty trays that had soaked in water for 15 min were placed upside down on the fruit-containing trays. The tray pockets were large enough so that the inoculumdrop on the fruit would not touch the surface of the top tray. The opening between trays was gently covered with Saran wrap to maintain high humidity levels. Peach trays were subsequently randomly assigned and incubated at $22^{\circ} \mathrm{C}$ for $18 \mathrm{~h}$. Orbit 3.6EC was applied either $6 \mathrm{~h}$ before inoculation (protective treatment) or $18 \mathrm{~h}$ after inoculation (curative treatment) at half (0.15 liters/ha) or full (0.3 liters/ha) label rate using $1,892.65$ liters of water per ha with a hand sprayer to runoff. Peaches were maintained at $22^{\circ} \mathrm{C}$, and disease incidence (percent diseased fruit) was evaluated 5 days after inoculation. The experiment was repeated three times.

Orchard site and artificial inoculation of peaches in the field. The experimental orchards were established in 1995 at the Musser Fruit Research Farm, Clemson University, using trees of 'Redskin' and 'Coronet' peaches and 'Redgold' nectarines. Tree spacing was $6 \mathrm{~m}$ within and between rows. Applications of phosmet (Imidan 70WSB) were used for insect control in 2-week intervals starting at petal fall (PF). Weed control was the same for all programs and followed standard southeastern U.S. recommendations (6).

Two fruit on each tree were artificially inoculated with a conidial suspension of M. fructicola to encourage uniform inoculum levels. To make the conidial suspension, the surface of a brown rot infected, sporulating fruit was scraped and added to $50 \mathrm{ml}$ of sterile water in a $250-\mathrm{ml}$ bottle with a screw cap. The conidial suspension was shaken vigorously, and small amounts $(0.5$ to $2 \mathrm{ml})$ were injected with a $50 \mathrm{cc}$ syringe underneath the surface of two fruit located on opposite sides of a tree.

Application of fungicides and harvest of fruit. Fungicide application programs were replicated four times in a randomized complete block design with single-tree replicates. Fungicides were applied by handgun to runoff (5.68 liters per tree) at $1,723 \mathrm{KPa}$ of pressure approximately 14 and 7 days before harvest. 'Redgold' trees were treated on 28 June and 9 July 2001, 7 and 17 July 2002, and 8 and 16 July 2003. 'Redskin' trees were treated on 11 and 18 July 2001, and 18 and 25 July 2002. 'Coronet' trees were treated on 18 and 24 June 2003. The fungicides in the following spray programs were applied: fenbucona- zole (Indar 75WSP), propiconazole-1 (Orbit 3.6EC), propiconazole-2 (applied in 2002 and 2003 only; Propimax 3.6EC), tebuconazole (applied in 2003 only; Elite 45DF), captan (Captan 50W), boscalid + pyraclostrobin-1 (Pristine 38WG), fenhexamid (Elevate 50WDG), and azoxystrobin (Abound 2.08F). The fungicide programs with fenbuconazole, propiconazole-1 and -2, and tebuconazole were designated DMI fungicide programs. A complete list of fungicide programs, formulations, and rates per hectare (total product) is listed in Table 1.

When fruit were at commercial shipping maturity (firm fruit but yellow background color on 25 to $50 \%$ of the fruit), an arbitrary sample, consisting of 48 fruit, was randomly harvested from each tree. Symptomless fruit were placed in two 24-pocket fiber trays. To prevent contamination, when a diseased fruit was encountered, a microcentrifuge tube was placed in the fiber tray instead of the diseased fruit. Trays were then packed in cardboard boxes and stored in an air-conditioned room at 22 to $24^{\circ} \mathrm{C}$. 'Redgold' nectarines and 'Redskin' peaches were harvested on 12 and 25 July 2001, respectively, and 25 July and 2 August 2002, respectively. 'Coronet' peaches and 'Redgold' nectarines were harvested 30 June and 22 July 2003, respectively. The total number of diseased fruit was counted at 4 and 7 days or 5 and 8 days (for 'Redgold' nectarines in 2001 only) after harvest. Disease incidence was expressed as percentage of diseased fruit.

Statistical analysis. Differences between mean $50 \%$ effective dose $\left(\mathrm{ED}_{50}\right)$ values of $M$. fructicola populations were determined using Kruskal-Wallis one-way analysis followed by all pairwise multiple comparison with Dunn's method $(P<$ 0.05; Sigmastat, SPSS Inc., Chicago, IL). Disease incidence in peach inoculation studies was adjusted to the controls prior to statistical analysis using the formula: (treatment \%/control \%) $\times 100$. Control adjusted datasets were subjected to analysis of variance using SAS version 6.12 (SAS Institute, Inc., Cary, NC). Mean separation was by Fisher's protected LSD $(P<0.05)$. Disease incidence in field trials was analyzed separately for each variety in each year and subjected to analysis of variance using Sigmastat (SPSS Inc.). Mean separation was by Fisher's protected LSD $(P<0.05)$.

\section{RESULTS}

In vitro sensitivity of single-spore isolates to propiconazole. DF and AP isolates from Georgia were significantly less sensitive to propiconazole when compared with the baseline DL isolates and the isolates from other commercial sites (Table 2). The $\mathrm{EC}_{50}$ values of isolates from all other commercial orchards were not statistically different from the baseline DL isolates $(P<0.05)$. The sensitivity factors 
ranged from 3.2 (population $\mathrm{JO}$ ) to 316.7 (population DL03; Table 2). Pooled isolates from commercial orchards in Georgia were significantly less sensitive than pooled isolates from commercial orchards in South Carolina according to MannWhitney Rank Sum Test $(P<0.001$; data not shown).

Sensitivity of selected $M$. fructicola isolates to propiconazole in peach inoculation studies. Disease incidence in untreated peaches used for treatment comparisons varied among isolates. Mean disease incidence values in the protective treatments were 84.0,63.9, 100.0, and $97.9 \%$ for isolates DL71, DL72, AP5, and AP6, respectively, and mean values in the curative treatments were $72.9,74.3$, 100.0 , and $93.8 \%$, respectively. For each isolate, disease incidence of treatment was calculated as percentage of the control (Table 3).
Propiconazole applied protectively or curatively at the full label rate resulted in significant differences in disease incidence between the two DL isolates and AP6; the AP5 isolate trended toward a greater disease incidence as well (Table 3). When propiconazole was applied protectively at half the label rate, disease incidence for the AP isolates exceeded that for the DL isolates, although no statistical differences were observed. When propiconazole was applied curatively at half the label rate, disease incidence was statistically greater for both AP isolates, again as compared with both DL isolates.

Weather and inoculation success. Precipitation levels varied during the 3-year period of this study, resulting in differential disease incidence in the test blocks. In 2001 , totals of $85 \mathrm{~mm}$ and $24 \mathrm{~mm}$ of precipitation occurred during the 3 weeks prior to harvest of 'Redgold' nectarines and 'Redskin' peaches, respectively. In 2002, spring and early summer were very dry in South Carolina and no precipitation occurred during the 3 weeks prior to harvest of both varieties. In contrast, rain was plentiful in 2003, with $220 \mathrm{~mm}$ and 239 $\mathrm{mm}$ of precipitation during the 3 weeks prior to harvest of the 'Coronet' peaches and 'Redgold' nectarines, respectively.

Conidia production on artificially inoculated peaches prior to the application of fungicide programs was dependent on weather conditions. Artificially inoculated peaches produced a thick layer of conidia on the fruit surface in 'Redgold' nectarines in 2001 and on both varieties in 2003 . During the hot (day/night temperatures averaging $29^{\circ} \mathrm{C}$ ) and dry weather 3 weeks before 'Redskin' harvest in 2001 and 2002 and during 'Redgold' harvest in 2002, artificially inoculated fruit dried out quickly and mummified within 2 days of

Table 1. Effect of fungicide programs on brown rot incidence on peaches (Redskin and Coronet) and nectarine (Redgold) fruit in 2001, 2002, and 2003 at different numbers of days after harvest

\begin{tabular}{|c|c|c|c|c|c|c|c|c|c|c|c|c|c|c|}
\hline \multirow{4}{*}{$\begin{array}{l}\text { Fungicide } \\
\text { program }\end{array}$} & \multirow{4}{*}{$\begin{array}{l}\text { Fungicide } \\
\text { formulation }\end{array}$} & \multirow[b]{4}{*}{ Rate/ha } & \multicolumn{12}{|c|}{ Disease incidence $(\%)^{\mathrm{z}}$} \\
\hline & & & \multicolumn{4}{|c|}{2001} & \multicolumn{4}{|c|}{2002} & \multicolumn{4}{|c|}{2003} \\
\hline & & & \multicolumn{2}{|c|}{ Redgold } & \multicolumn{2}{|c|}{ Redskin } & \multicolumn{2}{|c|}{ Redgold } & \multicolumn{2}{|c|}{ Redskin } & \multicolumn{2}{|c|}{ Redgold } & \multicolumn{2}{|c|}{ Coronet } \\
\hline & & & 5 & 8 & 4 & 7 & 4 & 7 & 4 & 7 & 4 & 7 & 4 & 7 \\
\hline \multirow{3}{*}{$\begin{array}{l}\text { Control } \\
\text { Fenbuconazole }\end{array}$} & Untreated & & $50.0 \mathrm{a}$ & $60.0 \mathrm{a}$ & $12.8 \mathrm{a}$ & $23.4 \mathrm{a}$ & $5.2 \mathrm{a}$ & $13.7 \mathrm{a}$ & $3.6 \mathrm{a}$ & $16.1 \mathrm{a}$ & $95.3 \mathrm{a}$ & $98.4 \mathrm{a}$ & $88.0 \mathrm{a}$ & $93.7 \mathrm{a}$ \\
\hline & Indar 75WSP + & $0.14 \mathrm{~kg}$ & & & & & & & & & & & & \\
\hline & Latron B1956 & 1.2 liters & $1.4 \mathrm{c}$ & $1.4 \mathrm{c}$ & $1.0 \mathrm{ab}$ & $2.8 \mathrm{ab}$ & $2.6 \mathrm{a}$ & $8.3 \mathrm{a}$ & $1.5 \mathrm{a}$ & $15.6 \mathrm{a}$ & $8.3 \mathrm{c}$ & $11.9 \mathrm{c}$ & $5.2 \mathrm{ef}$ & $5.2 \mathrm{f}$ \\
\hline Propiconazole-1 & Orbit 3.6EC & 0.3 liters & $2.4 \mathrm{c}$ & $2.8 \mathrm{c}$ & $1.0 \mathrm{ab}$ & $2.8 \mathrm{ab}$ & $1.0 \mathrm{a}$ & $4.2 \mathrm{a}$ & $2.6 \mathrm{a}$ & $7.8 \mathrm{a}$ & $15.1 \mathrm{c}$ & $27.1 \mathrm{c}$ & $5.2 \mathrm{ef}$ & $10.9 \mathrm{f}$ \\
\hline Propiconazole-2 & Propimax EC & 0.3 liters & $\ldots$ & $\ldots$ & $\ldots$ & $\ldots$ & $3.1 \mathrm{a}$ & $10.4 \mathrm{a}$ & $0.5 \mathrm{a}$ & $8.8 \mathrm{a}$ & $9.4 \mathrm{c}$ & $14.1 \mathrm{c}$ & $1.6 \mathrm{f}$ & $3.6 \mathrm{f}$ \\
\hline Tebuconazole & Elite 45DF + & $0.43 \mathrm{~kg}$ & & & & & & & & & & & & \\
\hline & Induce & $0.06 \% \mathrm{v} / \mathrm{v}$ & $\cdots$ & & $\cdots$ & $\cdots$ & . & $\cdots$ & $\cdots$ & $\cdots$ & $\cdots$ & & $7.3 \mathrm{~d}-\mathrm{f}$ & 7.8 ef \\
\hline Azoxystrobin & Abound 2.08F & 1.14 liters & $8.0 \mathrm{bc}$ & $11.1 \mathrm{bc}$ & $0.7 \mathrm{ab}$ & $1.7 \mathrm{ab}$ & $6.3 \mathrm{a}$ & $15.1 \mathrm{a}$ & $0.5 \mathrm{a}$ & $8.8 \mathrm{a}$ & $12.5 \mathrm{c}$ & $26.6 \mathrm{c}$ & $20.3 \mathrm{c}-\mathrm{e}$ & $30.7 \mathrm{~cd}$ \\
\hline $\begin{array}{l}\text { Boscalid + } \\
\text { pyraclostrobin-1 }\end{array}$ & Pristine & $0.74 \mathrm{~kg}$ & $5.2 \mathrm{c}$ & $9.0 \mathrm{c}$ & $1.7 \mathrm{ab}$ & $3.0 \mathrm{ab}$ & $2.6 \mathrm{a}$ & $7.3 \mathrm{a}$ & $1.5 \mathrm{a}$ & $6.2 \mathrm{a}$ & $11.5 \mathrm{c}$ & $20.8 \mathrm{c}$ & $5.7 \mathrm{ef}$ & $13.5 \mathrm{ef}$ \\
\hline $\begin{array}{l}\text { Boscalid + } \\
\text { pyraclostrobin-2 }\end{array}$ & Pristine & $1.04 \mathrm{~kg}$ & $5.6 \mathrm{c}$ & $8.3 \mathrm{c}$ & $0.0 \mathrm{~b}$ & $1.0 \mathrm{~b}$ & $2.1 \mathrm{a}$ & $9.9 \mathrm{a}$ & $0.5 \mathrm{a}$ & $14.1 \mathrm{a}$ & $14.6 \mathrm{c}$ & $24.5 \mathrm{c}$ & $29.6 \mathrm{bc}$ & $34.4 \mathrm{bc}$ \\
\hline Fenhexamid & $\begin{array}{l}\text { Elevate } \\
\text { 50WDG }\end{array}$ & $1.70 \mathrm{~kg}$ & $17.3 \mathrm{~b}$ & $21.9 \mathrm{~b}$ & $0.0 \mathrm{~b}$ & $0.3 \mathrm{~b}$ & $3.7 \mathrm{a}$ & $8.3 \mathrm{a}$ & $2.1 \mathrm{a}$ & $6.8 \mathrm{a}$ & $42.6 \mathrm{~b}$ & $57.8 \mathrm{~b}$ & $17.7 \mathrm{c}-\mathrm{e}$ & $20.8 \mathrm{c}-\mathrm{e}$ \\
\hline Captan & Captan 50W & $9.07 \mathrm{~kg}$ & $10.5 \mathrm{bc}$ & $17.4 \mathrm{bc}$ & $0.7 \mathrm{ab}$ & $2.8 \mathrm{ab}$ & $2.6 \mathrm{a}$ & $5.7 \mathrm{a}$ & $3.1 \mathrm{a}$ & $6.8 \mathrm{a}$ & $52.6 \mathrm{~b}$ & $67.7 \mathrm{~b}$ & $44.8 \mathrm{~b}$ & $46.3 \mathrm{~b}$ \\
\hline
\end{tabular}

$\mathrm{z}$ Values within a column for each year followed by the same letter are not significantly different based on ANOVA followed by Fisher's protected LSD $(P<$ 0.05). Values are means of four replicates, each replicate consisted of 48 peaches.

Table 2. Characteristics of Monilinia fructicola isolates from South Carolina and Georgia and their sensitivity to propiconazole

\begin{tabular}{|c|c|c|c|c|c|c|c|}
\hline \multicolumn{3}{|c|}{ Origin of isolates $^{x}$} & \multirow{2}{*}{$\begin{array}{c}\text { Year of } \\
\text { isolation }\end{array}$} & \multirow{2}{*}{$\begin{array}{l}\text { No. of } \\
\text { isolates }\end{array}$} & \multicolumn{2}{|c|}{ EC $_{50}$ values $(\mu \mathrm{g} / \mathrm{ml})$} & \multirow{2}{*}{$\begin{array}{c}\text { Sensitivity } \\
\text { factor }^{\mathrm{z}}\end{array}$} \\
\hline State & County & Orchard & & & Range & Meany $^{y}$ & \\
\hline GA & Crawford & DF & 2002 & 12 & $0.012-0.913$ & $0.216 \mathrm{~b}$ & 76.1 \\
\hline GA & Hall & JO & 2002 & 12 & $0.011-0.035$ & $0.027 \mathrm{a}$ & 3.2 \\
\hline GA & Macon & AP & 2003 & 8 & $0.007-0.435$ & $0.224 \mathrm{~b}$ & 62.1 \\
\hline GA & Peach & DL03 & 2003 & 18 & $0.003-0.950$ & $0.021 \mathrm{a}$ & 316.7 \\
\hline GA & Peach & LO & 2002 & 11 & $0.019-0.217$ & $0.081 \mathrm{a}$ & 11.1 \\
\hline $\mathrm{SC}$ & Anderson & DL & 2001 & 33 & $0.012-0.054$ & $0.025 \mathrm{a}$ & 4.5 \\
\hline $\mathrm{SC}$ & Anderson & $\mathrm{EZ}$ & 2001 & 9 & $0.003-0.014$ & $0.010 \mathrm{a}$ & 4.7 \\
\hline $\mathrm{SC}$ & Edgefield & SY & 2001 & 15 & $0.003-0.027$ & $0.013 \mathrm{a}$ & 9.0 \\
\hline $\mathrm{SC}$ & Saluda & $\mathrm{CC} 02$ & 2001 & 13 & $0.002-0.034$ & $0.014 \mathrm{a}$ & 17.0 \\
\hline $\mathrm{SC}$ & Saluda & $\mathrm{CC} 03$ & 2003 & 21 & $0.001-0.074$ & $0.036 \mathrm{a}$ & 74.0 \\
\hline $\mathrm{SC}$ & York & BS & 2003 & 31 & $0.005-0.049$ & $0.022 \mathrm{a}$ & 9.8 \\
\hline $\mathrm{SC}$ & York & $\mathrm{MC}$ & 2003 & 14 & $0.015-0.175$ & $0.047 \mathrm{a}$ & 11.7 \\
\hline
\end{tabular}

${ }^{\mathrm{x}}$ Isolates were obtained from established peach orchards (at least 7 years old) that either had not been exposed to DMI fungicides (DL orchard) or had been subjected regularly to two to five DMI fungicide applications for at least 3 years (all other orchards). Isolates from orchards with DMI history were collected from areas with brown rot incidence despite DMI fungicide treatments in the collection year.

y Values within a column followed by the same letter are not significantly different $(P<0.05)$ based on the Kruskal-Wallis one-way analysis followed by all pairwise multiple comparison with Dunn's method.

${ }^{\mathrm{z}}$ Sensitivity factors for a population were calculated by dividing the highest $50 \%$ effective dose $\left(\mathrm{EC}_{50}\right)$ value by the lowest $\mathrm{EC}_{50}$ value of isolates within a population. 
inoculation. No conidia were visible on those mummies.

Field performance of fungicide programs. Significant differences between fungicide programs were observed in 'Redgold' in 2001 and in both varieties in 2003, when disease incidence was high (50\% brown rot in the control). The DMI fungicides fenbuconazole and propiconazole were often statistically superior to non-DMI fungicides $(P<0.05)$. The boscalid + pyraclostrobin-1 and -2 programs and the azoxystrobin program were as effective as DMI fungicide programs with the exception of boscalid + pyraclostrobin-2 and azoxystrobin in 'Coronet' peaches in 2003. Captan and fenhexamid programs were significantly less effective when compared to the DMI fungicide programs in both varieties in 2003 and in the 'Redgold' nectarines in 2001.

\section{DISCUSSION}

The significantly higher mean $\mathrm{EC}_{50}$ values of $M$. fructicola populations from Georgia orchards AP and DF are likely to be the result of a sensitivity shift rather than of innate higher tolerance. This conclusion is based on the assumption that the mean baseline sensitivity to propiconazole in M. fructicola populations for $50 \%$ suppression of mycelial growth $\left(\mathrm{EC}_{50}\right)$ is significantly higher for populations from orchards AP and DF than from baseline orchards. Unfortunately, we were able to find only one orchard for collecting baseline isolates, because DMI fungicides are so widely used for brown rot control in South Carolina and Georgia peach orchards. However, the baseline sensitivity determined in this study was likely representative for baseline populations from the eastern United States because it was consistent with previously published baseline sensitivities in $M$. fructicola from New York and South Carolina (17,22). Studies conducted with tebuconazole, a DMI fungicide with comparable efficacy against $M$. fructicola in laboratory (17) and field studies $(15,16)$, revealed mean sensitivity values even lower than for propiconazole. Specifically, $\mathrm{EC}_{50}$ values for $M$. fructicola baseline populations from California and New York were reported to be 0.0161 $\mu \mathrm{g} / \mathrm{ml}(21)$ and $0.007 \mu \mathrm{g} / \mathrm{ml}$ (17), respectively.
A significant shift toward reduced sensitivity to propiconazole in $M$. fructicola populations from commercial peach orchards from South Carolina was not detected in this study, even after more than 15 years of repeated DMI fungicide use. This is in contrast to results obtained in a previous study, in which $M$. fructicola isolates with reduced sensitivity to propiconazole were obtained from commercial South Carolina orchards (22). In fact, mean $\mathrm{EC}_{50}$ values for some South Carolina populations from commercial orchards obtained in this study were moderately lower than mean $\mathrm{EC}_{50}$ values from our baseline population or from South Carolina populations published previously (22). The differences may be attributed to a smaller sample size in this study, differences in the experimental setup, or the use of different collection sites in South Carolina. Alternatively, the results could indicate that sensitivity levels in $M$. fructicola populations from South Carolina may have actually increased slightly over time. For the current study, the reason for the greater prevalence of isolates with reduced sensitivity to propiconazole in Georgia than in South Carolina is not clear. The climate in both states is similar, and commercial peach orchards in each state, to the best of our knowledge, have comparable DMI fungicide use history. However, reduced sensitivity to the DMI fungicide propiconazole has now been documented in Georgia, as previously reported in South Carolina. This development calls for consistent implementation of resistance management strategies in the southeastern United States.

Even though differences in $\mathrm{EC}_{50}$ values between the baseline DL isolates and commercial populations from South Carolina were not detected, the range of $\mathrm{EC}_{50}$ values differed. The $\mathrm{EC}_{50}$ sensitivity factors were consistently higher in populations from commercial orchards in South Carolina and in most commercial orchards from Georgia compared with the population from the baseline DL orchard. This is consistent with results published previously, showing that the range of $\mathrm{EC}_{50}$ values may widen in $M$. fructicola populations with prolonged exposure to DMI fungicides (22).

M. fructicola populations with reduced sensitivity to DMI fungicides in vitro may not be controlled as effectively in the field. This conclusion is based on our data showing that isolates with high $\mathrm{EC}_{50}$ values were or tended to be more difficult to control in peach inoculation studies than isolates with low $\mathrm{EC}_{50}$ values. It is possible that the latest outbreaks of brown rot in Georgia (harvest seasons in 2001 and 2003) may have resulted from reduced sensitivity in $M$. fructicola populations, perhaps in combination with favorable wet conditions for disease epidemics. Indeed, reduced sensitivity was found in Georgia isolates from orchard AP (Macon County), an orchard that was selected for this study because of brown rot control failure despite DMI fungicide applications. Pooled populations from commercial orchards in South Carolina had lower EC $_{50}$ values than those from Georgia, which is consistent with observations that brown rot incidence in South Carolina is lower than in Georgia. The reason for this is not known. A preliminary survey of South Carolina and Georgia growers indicated that South Carolina growers use at least as many or even more applications of DMI fungicides for brown rot control.

Our data have important implications for modern brown rot control strategies. The selection for isolates with reduced sensitivity to DMI fungicide needs to be slowed or prevented if DMI fungicides are to be used effectively in future spray programs. One option would be to alternate the DMI fungicides with products exhibiting different modes of action. In this study, we compared three commonly used DMI fungicides for brown rot control in the southeastern United States with captan and three recently registered products with different modes of action. Other products registered for brown rot control, such as thiophanate methyl, sulfur, dodine, and myclobutanil, were not included because they are not recommended in current spray guides due to lack of efficacy, danger to applicators, or fungicide resistance concerns (6).

The DMI fungicide programs fenbuconazole and propiconazole-1 controlled brown rot reliably and were among the most efficacious programs in all experimental years. This result is consistent with studies examining the efficacy of DMI fungicides for brown rot control in experimental peach orchards from Virginia and

Table 3. Effect of propiconazole treatments on brown rot disease incidence on peach fruit

\begin{tabular}{|c|c|c|c|c|c|c|c|}
\hline \multirow[b]{3}{*}{ Isolate } & \multirow[b]{3}{*}{ EC $_{50}$ value $^{\mathrm{z}}$} & \multicolumn{6}{|c|}{ Relative disease incidence $(\%)^{y}$} \\
\hline & & \multicolumn{3}{|c|}{ Propiconazole (liters/ha), protective treatment } & \multicolumn{3}{|c|}{ Propiconazole (liters/ha), curative treatment } \\
\hline & & $\mathbf{0}$ & 0.15 & 0.3 & $\mathbf{0}$ & 0.15 & $\mathbf{0 . 3}$ \\
\hline DL71 & 0.02 & 100.0 & $54.5 \mathrm{a}$ & $42.2 \mathrm{a}$ & 100.0 & $21.0 \mathrm{a}$ & $14.3 \mathrm{a}$ \\
\hline DL72 & 0.02 & 100.0 & $58.7 \mathrm{a}$ & $42.4 \mathrm{a}$ & 100.0 & $25.2 \mathrm{a}$ & $15.0 \mathrm{a}$ \\
\hline AP5 & 0.42 & 100.0 & $85.4 \mathrm{a}$ & $72.9 \mathrm{ab}$ & 100.0 & $60.4 \mathrm{~b}$ & $32.7 \mathrm{ab}$ \\
\hline AP6 & 0.43 & 100.0 & $89.3 \mathrm{a}$ & $86.6 \mathrm{~b}$ & 100.0 & $83.7 \mathrm{~b}$ & $42.2 \mathrm{~b}$ \\
\hline
\end{tabular}

y Values within a column followed by the same letter are not significantly different based on an ANOVA followed by Fisher's protected LSD $(P<0.05)$

Values are means of three independent experiments and are shown as percentage of the control.

${ }^{\mathrm{z}}$ The 50\% effective dose $\left(\mathrm{EC}_{50}\right)$ values were determined in mycelial growth tests and represent means of three different experiments. 
North Carolina $(9,19)$. No difference in efficacy was observed between DMI fungicide programs in any experimental year. Results from 2003 indicate that the propiconazole- 2 and propiconazole-1 programs were comparable, suggesting that the two formulations of propiconazole are equally effective for brown rot control. The tebuconazole program was as efficacious as other DMI fungicide programs, but the treatment was only included in one experimental year in one variety, which allows no conclusion about performance consistency.

With few exceptions, azoxystrobin and boscalid + pyraclostrobin were as effective as the DMI fungicides, indicating that these may be suitable rotation partners for DMI fungicides. Other studies have confirmed that the fungicidal activity of the boscalid + pyraclostrobin program against brown rot may be equal or even superior to DMI fungicides $(2-4,13)$. Similarly, azoxystrobin was very often found to be as effective as DMI programs $(7,10-12,20)$.

The efficacy of DMI treatments decreased with increasing disease incidence in the nontreated control. For example, disease incidences in the Indar and Orbit programs were 1.4 and $2.4 \%$, respectively, when disease incidence was $50.0 \%$ in the nontreated control; $5.2 \%$ for both programs when disease incidence was $88.0 \%$ in the nontreated control; and 8.3 and $15.1 \%$, respectively, when disease incidence was $95.3 \%$ in the nontreated control. These results indicate that even DMI fungicides cannot provide adequate control if disease pressure is high. The experimental block was located $500 \mathrm{~m}$ from an orchard where isolates with reduced sensitivity had been detected in the mid-1990s (22), and it is therefore possible that the documented tendency to lose control as disease pressure increased was related to the presence of these isolates. To achieve acceptable brown rot control with preharvest fungicide applications, measures to reduce inoculum levels must be implemented in commercial peach orchards during dormancy, bloom, fruit expansion, and prior to harvest-a season-long effort. These measures become even more important when warm and humid environmental conditions, which are frequently found in the southeastern United States, favor disease epidemics.

\section{ACKNOWLEDGMENTS}

We thank Curt Powell, Jim Henderson, Eric Hitzler, Anne Knowlton, and Rachel Keith for technical assistance.

\section{LITERATURE CITED}

1. Anonymous. 2002. Pristine Fungicide; Technical Information Bulletin. BASF Corporation, Raleigh, NC.

2. Brannen, P. M., Hotchkiss, M., and Reilly, C. C. 2002. Efficacy of fungicides for control of brown rot in an early-ripening peach variety in middle Georgia, 2001. Fungic. Nematicide Tests 57.

3. Brannen, P. M., Hotchkiss, M., and Reilly, C. C. 2002. Efficacy of fungicides for control of brown rot in a mid-ripening peach variety in middle Georgia, 2001. Fungic. Nematicide Tests 57:STF32.

4. Brannen, P. M., Hotchkiss, M., and Reilly, C. C. 2002. Efficacy of fungicides for control of brown rot in a late-ripening peach variety in middle Georgia, 2001. Fungic. Nematicide Tests 57:STF34.

5. Hong, C., Michailides, T. J., and Holtz, B. A. 1998. Effects of wounding, inoculum density, and biological control agents on postharvest brown rot of stone fruits. Plant Dis. 82:12101216.

6. Horton, D., Gorsuch, C., and Ritchie, D. 2001. 2001 Southern peach, nectarine and plum pest management and culture guide. University of Georgia, Athens.

7. Lalancette, N., and Robison, D. 2000. Scab and brown rot management on peach, 1999. Fungic. Nematicide Tests 55:59.

8. Ogawa, J. M., Manji, B. T., Bostock, R. M., Canez, V. M., and Bose, E. A. 1984. Detection and characterization of benomyl-resistant Monilinia laxa on apricots. Plant Dis. 68:29-31.

9. Ritchie, D., and Pollard, D. W. 2003. Evaluation of preharvest fungicide sprays for control of peach fruit brown rot, 2002. Fungic. Nematicide Tests 58:STF013.

10. Ritchie, D. F., and Pollard, D. W. 2000. Postharvest residual effects of preharvest sprays of orbit and abound on brown rot, 1999. Fungic. Nematicide Tests 55:62.
11. Ritchie, D. F., and Pollard, D. W. 2000. Evaluation of fungicides for control of fruit brown rot and scab on peach. Fungic. Nematicide Tests 55:63.

12. Ritchie, D. F., and Pollard, D. W. 2001. Evaluation of fungicides for control of scab and brown rot of peaches, 2000. Fungic. Nematicide Tests 56:STF7.

13. Ritchie, D. F., and Pollard, D. W. 2002. Evaluation of preharvest fungicide sprays for control of brown rot of peach fruit, 2001. Fungic. Nematicide Tests 57:STF16.

14. Rohel, E. A., Cavelier, N., and Hollomon, D. W. 2001. Microscopic analysis of the effect of azoxystrobin treatments on Mycosphaerella graminicola infection using green fluorescent protein (GFP)-expressing transformants. Pest Manag. Sci. 57:1017-1022.

15. Schnabel, G., and Powell, R. C. 2002. Preharvest fungicide sprays for control of peach/nectarine fruit decay, 2001. Fungic. Nematicide Tests 57:25.

16. Schnabel, G., and Powell, R. C. 2003. Preharvest fungicide sprays for control of peach/nectarine fruit decay $4,7,10$ and 13 days after harvest. Fungic. Nematicide Tests 58:STF004

17. Wilcox, W. F., and Burr, J. A. 1994. Base-line sensitivity of Monilinia fructicola to six DMI fungicides. (Abstr.) Phytopathology 84:1078.

18. Wong, F. P., and Wilcox, W. F. 2002. Sensitivity to azoxystrobin among isolates of Uncinula necator: Baseline distribution and relationship to myclobutanil sensitivity. Plant Dis. 86:394404.

19. Yoder, K. S., Cochran, A. E. I., Royston, W. S., and Kilmer, S. W. 1995. Effects of pre-harvest fungicide treatments on pre-harvest and postharvest disease development on redskin peach Fungic. Nematicide Tests 50:63.

20. Yoder, K. S., Cochran, A. E. I., Royston, W. S., and Kilmer, S. W. 2002. Evaluation of fungicide schedules for brown rot control on peach and nectarine, 2001. Fungic. Nematicide Tests 57:STF23.

21. Yoshimura, M. A., Luo, Y., Ma, Z., and Michailides, T. J. 2004. Sensitivity of Monilinia fructicola from stone fruit to thiophanatemethyl, iprodione, and tebuconazole. Plant Dis. 88:373-378.

22. Zehr, E. I., Luszcz, L. A., Olien, W. C., Newall, W. C., and Toler, J. E. 1999. Reduced sensitivity in Monilinia fructicola to propiconazole following prolonged exposure in peach orchards. Plant Dis. 83:913-916.

23. Zehr, E. I., Toler, J. E., and Luszcz, L. A. 1991. Spread and persistence of benomyl-resistant Monilinia fructicola in South Carolina peach orchards. Plant Dis. 75:590-593. 